\title{
ANALISIS TINGKAT KEMAMPUAN BERPIKIR KRITIS GELOMBANG MEKANIK MELALUI PEMBELAJARAN DENGAN PENDEKATAN KONFLIK KOGNITIF
}

\author{
Zul Hidayatullah*, Muh. Makhrus, I Wayan Gunada \\ Program Studi Pendidikan Fisika, Universitas Mataram \\ *Email: zulhidayatullah5@gmail.com
}

\begin{abstract}
This study aims to analyze the critical thinking level of mechanical wave in the studentsof MAN 2 Mataram through cognitive conflict approach. This research is a pre-experimentalstudy with design only pretest-posttest group design. The population in this study is all students of class XIMIA MAN 2 Mataram, amounting to 257 students. Research sampling using purposive sampling technique, so selected XI class MIA 1, XI MIA 2, and XI MIA 4 as an experimental class that willbe given treatment in the form of cognitive conflict approach. Data collection of critical thinking ability is done by description test as much as 5 problems and at the learning process obtained through LKPD. The results of hypothesis test analysis using parametric test paired sample t test and show that $H_{o}$ rejected and $H_{a}$ accepted, while the level of critical thinking ability included in category is very highforclass XIMIA 1 and high category for class XI MIA 2 and XI MIA 4. The cognitive conflictapproach applied successfully to increase the critical thinking ability.
\end{abstract}

Keywords: Critical thinking ability, cognitive conflict approach.

\section{PENDAHULUAN}

Pendidikan haruslah mampu memfasilitasi peserta didik untuk dapat bersaing sesuai dengan perkembangan zamannya. Tuntutan terhadap peningkatan mutu pendidikan, khususnya pembelajaran fisika dewasa ini makin terasa. Aspek-aspek penting yang perlu diperhatikan selain teknis pembelajaran adalah aspek moral dan nilainilai (values) dalam pembelajaran, bukan hanya sekedar pernyataan tentang fakta, konsep, teori maupun hukum-hukum dalam ilmu pengetahuan. Pendidikan dilaksanakan dengan tujuan untuk mempersiapkan peserta didik agar mampu bersaing dalam kehidupan bermasyarakat. Pendidikan di dalam sekolah memiliki peran yang sangat penting untuk mempersiapkan peserta didik dengan sebaik-baiknya (Tuqalby et al, 2017). Belajar adalah suatu proses yang kompleks yang dapat terjadi pada diri setiap orang sepanjang hidupnya. Pembelajaran merupakan perubahan yang bertahan lama dalam perilaku, atau dalam kapasitas berperilaku dengan cara tertentu, yang dihasilkan dari praktik atau bentuk-bentuk pengalaman lainnya (Schunk, 2012). Sardiman (dalam Mutmainnah et al, 2017) mengatakan pembelajaran fisika merupakan proses belajar mengajar untuk mencapai tujuan dan hasil belajar fisika. Pendidikan perlu ditempatkan dalam konteks pembentukan manusia seutuhnya sesuai tujuan pendidikan nasional yang tercantum dalam UU Sistem Pendidikan Nasional No.20 Tahun 2003 yaitu untuk mengembangkan potensi peserta didik agar menjadi manusia beriman dan bertakwa kepada Tuhan Yang Maha Esa, Berahlak mulia, sehat berilmu, cakap, kreatif, mandiri, dan menjadi warga negara yang demokratis, serta bertanggung jawab.

Faktanya di lapangan masih terdapat gejala yang menandai tidak efektifnya pembelajaran di sekolah. Satu diantaranya masih banyak sistem pembelajaran di sekolah yang berjalan secara tradisional yang menghambat peserta didik untuk belajar secara aktif-kreatif. Fakta ini menyebabkan penguasaan konsep peserta didik relatif masih rendah, sehingga 
diperlukan reorientasi dan pendekatan baru yang lebih efektif dalam pembelajaran, khususnya pembelajaran pada mata pelajaran fisika.

Fisika merupakan bagian dari Ilmu Pengetahuan Alam (IPA) atau sains. Gunawan et al. (2015), fisika merupakan bagian dari sains yang memfokuskan kajiannya pada materi, energi, dan hubungan antara keduanya. Sains tidak hanya terdiri dari kumpulan yang terisolasi satu dengan lainnya melainkan kumpulan ilmu pengetahuan yang terorganisasi secara sistermatis. Sains dapat dipandang sebagai proses, produk, dan sikap ilmiah. Sains sebagai produk berbentuk konsep, prinsip, teori, dan hukum. Sains sebagai proses dipandang sebagai metode ilmiah dan sebagai sikap yaitu jujur, terbuka, objektif, dan kritis (Makhrus, 2012).

Studi pendahuluan yang dilakukan peneliti melalui observasi dan wawancara dengan peserta didik dan guru mata pelajaran fisika kelas XI MAN 2 Mataram, bahwa mata pelajaran fisika sering dianggap sebagai pelajaran yang sulit, terlalu banyak rumus, dan membosankan. Masalah ini akan membawa pola pikir peserta didik pada pembelajaran yang sangat monoton, di samping itu guru dalam proses pembelajaran kurang memperhatikan konsep awal peserta didik. Peserta didik beranggapan bahwa apa yang dipelajari tanpa ada arti karena tidak ada kaitannya dengan pembelajaran yang lalu maupun dengan peristiwa yang ada dalam kehidupan nyata di lingkungannya

Kemampuan berpikir peserta didik juga jarang diasah, khususnya kemampuan berpikir kritis. Muhfahroyin (dalam Setyowati et al, 2011) menyatakan kemampuan berpikir kritis merupakan proses kognitif untuk memperoleh pengetahuan. Kemampuan berpikir kritis adalah kemampuan peserta didik untuk membandingkan dua atau lebih informasi dengan tujuan memperoleh pengetahuan melalui pengujian terhadap gejala-gejala menyimpang dan kebenaran ilmiah. Ennis (1996) menyatakan terdapat enam unsur dasar dalam berpikir kritis yang disingkat dengan FRISCO yaitu F (Focus), untuk membuat sebuah keputusan tentang apa yang diyakini maka harus bisa memperjelas pertanyaan atau isu tertentu. $\mathrm{R}$ (Reason), mengetahui alasan-alasan yang mendukung atau bertentangan dengan situasi dan fakta yang relevan. I (Inference), membuat kesimpulan yang beralasan atau menyuguhkan. S (Situation), memahami situasi dan selalu menjaga situasi dalam berpikir. C (Clarity), menjelaskan arti atau istilah-istilah yang digunakan. $\mathrm{O}$ (Overview), melangkah kembali dan meneliti secara menyeluruh keputusan yang diambil. King et al. (dalam Arend, 2009), berpikir kritis dilihat sebagai keterampilan hidup yang diperlukan di mana proses peningkatan berpikir, pada dasarnya menciptakan kebiasaan refleksi dan mempertanyakan setiap aspek kehidupan.

Perbaikan dalam kegiatan pembelajaran perlu dilakukan agar kemampuan berpikir kritis peserta didik dapat meningkat. Salah satu alternatif pemecahan masalahnya adalah dengan menggunakan pendekatan konflik kognitif. Lee et al. (2003), konflik kognitif adalah sebuah keadaan di mana peserta didik merasa adanya ketidakcocokan antara struktur kognitif mereka dengan keadaan lingkungannya. Pendekatan konflik kognitif menghadapkan peserta didik pada situasi yang bertentangan dengan konsep awal yang dimiliki, kemudian diarahkan pada percobaan atau demonstrasi untuk membuktikan kebenaran konsep tersebut. Fase-fase dalam pendekatan konflik kognitif didasarkan pada pendapat Lee et al. (2003), yakni fase permulaan (preliminary stage), fase konflik (conflict stage), dan fase penyelesaian (resolution stage). Pembelajaran dengan pendekatan konflik 
kognitif memberikan kesempatan kepada peserta didik untuk mengungkapkan konsepsinya dan mengkritisi pembelajaran yang berbeda dengan konsepsinya. Pendekatan konflik kognitif membuat peserta didik terlibat langsung dalam proses pembelajaran, sehingga di akhir pembelajaran diharapkan peserta didik dapat menguasai konsep dengan baik dan meningkatkan kemampuan berpikirnya, khususnya kemampuan berpikir kritis.

Penelitian ini bertujuan untuk menganalisis tingkat kemampuan berpikir kritis pada saat proses pembelajaran dengan pendekatan konflik kognitif dan pada saat hasil pembelajaran. Indikator kemampuan berpikir kritis yang digunakan dalam penelitian ini yaitu: 1) Klarifikasi dasar; 2) Keputusan dasar; 3) Inferensi; 4) Penjelasan lebih lanjut; 5) Menalar.

\section{METODE PENELITIAN}

Jenis penelitian yang digunakan adalah penelitian pre-experimental dengan desain Only One Group Pretest-Posttest. Populasi dalam penelitian ini adalah seluruh peserta didik kelas XI MIA di MAN 2 Mataram tahun ajaran 2017/2018 yang berjumlah 6 kelas. Sampel adalah bagian dari populasi. Sampel yang digunakan dipilih dengan menggunakan teknik purposive sampling. Kemampuan berpikir kritis diukur melalui LKPD dan tes uraian berpikir kritis sebanyak 5 soal. Perlakukan berupa pendekatan konflik kognitif. Ketiga kelompok sampel diberikan tes awal untuk mengukur kondisi awal dan tes akhir untuk mengetahui hasil perlakuan.

Hipotesis penelitian ini diuji menggunakan uji $\mathrm{t}$ berpasangan atau paired sample $t$ test. Uji t berpasangan ini untuk mengetahui apakah terdapat perbedaan atau tidak terhadap rata-rata skor pretest dan skor posttest setelah pembelajaran dengan pendekatan konflik kognitif. Tingkat kemampuan berpikir kritis saat proses pembelajaran dianalisis dengan statistik deskriptif.

\section{HASIL DAN PEMBAHASAN}

Penelitian ini bertujuan untuk menganalisis tingkat kemampuan berpikir kritis pada saat proses dan hasil pembelajaran dengan pendekatan konflik kognitif. Treagust (2013) mengatakan pendekatan konflik kognitif adalah keadaan di mana peserta didik merasa ada informasi yang kontradiktif yang mempengaruhi gagasan dalam struktur kognitifnya, dan karenanya mereka dihadapkan pada situasi baruuntuk memecahkan masalah dalam pembelajaran, sehingga tercipta konsep yang baru. Tingkat kemampuan berpikir kritis peserta didik pada saat pembelajaran diukur melalui LKPD yang dilengkapi instrumen kemampuan berpikir kritis. Kategori tingkat kemampuan berpikir kritis peserta didik pada saat pembelajaran di kelas XI MIA 1 termasuk dalam kategori sangat tinggi, sedangkan pada kelas XI MIA 2 dan XI MIA 4 termasuk dalam kategori tinggi. Tingkat kemampuan berpikir kritis yang tinggi ini terjadi karena peserta didik memiliki konsepsi yang beragam dan konsepsi tersebut masih keliru. Peserta didik banyak mengalami ketidakcocokan antara konsepsinya dengan fakta (konsep ilmiahnya), sehingga terjadi perubahan konseptual melalui proses asimilasi dan akomodasi pada saat pembelajaran dengan konflik kognitif. Piaget (dalam Sagala, 2009) mengatakan ada dua proses yang terjadi dalam perkembangan dan pertumbuhan kognitif anak yaitu: (1) proses "assimilation", dalam proses ini menyesuaikan dan mencocokkan informasi yang baru dengan apa yang telah diketahui; dan (2) proses "accommodation" yaitu anak menyusun dan membangun kembali atau mengubah apa yang telah diketahui sebelumnya, sehingga informasi yang baru itu dapat disesuaikan dengan yang lebih 
baik.Berdasarkan hal tersebut, maka pendekatan konflik kognitif sangat penting untuk meningkatkan kemampuan berpikir kritis peserta didik. Pendapat ini sesuai dengan hasil penelitian Wiradana (2012) yang menyimpulkan bahwa pendekatan konflik kognitif menuntut kemampuan berpikir lebih pada saat proses pemberian konflik dalam rangka mengubah miskonsepsi yang dimiliki. Hasil analisis tingkat kemampuan berpikir kritis pada saat pembelajaran dapat diamati pada Tabel 1.

Tabel 1. Tingkat Kemampuan Berpikir Kritis pada saat Pembelajaran dengan Pendekatan Konflik Kognitif

\begin{tabular}{lccccccc}
\hline \multirow{2}{*}{ Kelas } & \multicolumn{4}{c}{ Tingkat Kemampuan } & Berpikir Kritis & Rata- & \multirow{2}{*}{ Kategori } \\
\cline { 2 - 6 } & A & B & C & D & E & rata & \\
\hline XI MIA 1 & 88,68 & 89,08 & 85,00 & 93,69 & 83,16 & 87,92 & ST \\
\hline XI MIA 2 & 80,59 & 88,82 & 68,97 & 64,41 & 71,76 & 74,91 & T \\
\hline XI MIA 4 & 70,71 & 77,00 & 71,14 & 57,71 & 42,00 & 63,71 & T \\
\hline
\end{tabular}

Keterangan:

A: Klarifikasi Dasar, B: Keputusan Dasar, C: Inferensi, D: Penjelasan Lebih Lanjut, E: Menalar dan Pengintegrasian, ST: Sangat Tinggi, T: Tinggi.

Hasil analisis tingkat kemampuan berpikir kritis ini dapat dilihat juga pada Gambar 1. Tabel 1 menunjukkan tingkat kemampuan berpikir kritis saat pembelajaran pada ketiga kelas eksperimen. Indikator keputusan dasar mengalami peningkatan tertinggi dan terendah pada indikator menalar. Indikator menalar merupakan indikator tingkat tinggi pada kemampuan berpikir kritis, sehingga tidak semua peserta didik mampu menguasainya. Kemampuan berpikir kritis yang berkaitan dengan produk pembelajaran diperoleh melalui tes tertulis berbentuk uraian yang terdiri dari 5 item soal dan tiap item soal mewakili satu indikator kemampuan berpikir kritis.

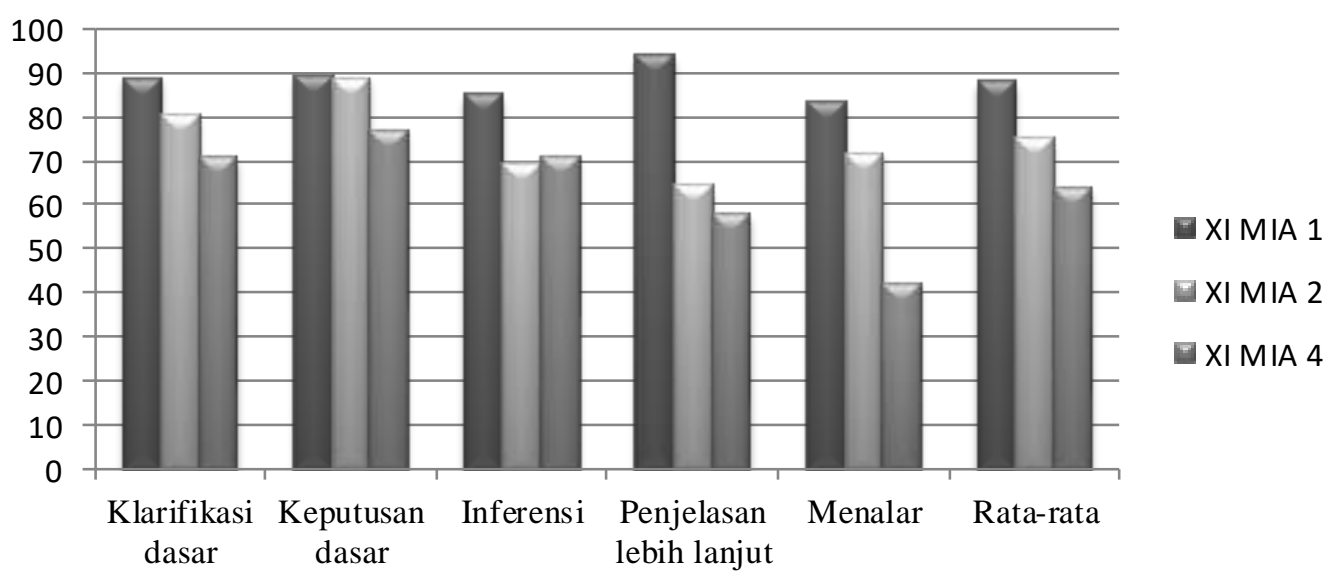

Gambar 1. Tingkat kemampuan berpikir kritis pada saat pembelajaran dengan pendekatan konflik kognitif

Kemampuan berpikir kritis peserta didik berpikir kritis setelah diberikan perlakuan sebelum diberikan perlakuan terlihat dari terlihat dari nilai tes akhir (pos-test) seperti nilai tes awalnya (pre-test), dan kemampuan terlihat pada Tabel 2.

Tabel 2. Hasil Pretest dan Posttest Kemampuan Berpikir Kritis

\begin{tabular}{lccl}
\hline \multirow{2}{*}{ Kelas } & Hasil Tes Kemampuan & Berpikir Kritis & \multirow{2}{*}{ Keterangan } \\
\cline { 2 - 3 } & Pretest & Posttest & Meningkat \\
\hline XI MIA 1 & 24,21 & 60,39 & Meningkat \\
\hline XI MIA 2 & 25,88 & 53,24 & Meningkat \\
\hline XI MIA 3 & 21,00 & 65,29 & \\
\hline
\end{tabular}


Rata-rata nilai pretest peserta didik pada tiap kelas eksperimen untuk kemampuan berpikir kritis masih tergolong rendah. Rata-rata nilai kemampuan berpikir kritis peserta didik pada kelas XI MIA 1 sebesar 24,21, kelas XI MIA 2 sebesar 25,88, dan kelas XI MIA 4 sebesar 21,00. Pembelajaran dengan pendekatan konflik kognitif mampu meningkatkan kemampuan berpikir kritis peserta didik.

Fakta ini dapat dilihat dari hasil posttest pada tiga kelas eksperimen. Hasil posttest menunjukkan bahwa nilai-rata kemampuan berpikir kritis kelas XI MIA 1 sebesar 60,39, kelas XI MIA 2 sebesar 53,24, dan kelas XI MIA 4 sebesar 65,29. Secara grafik, peningkatan kemampuan berpikir kritis dapat dilihat pada Gambar 2 .

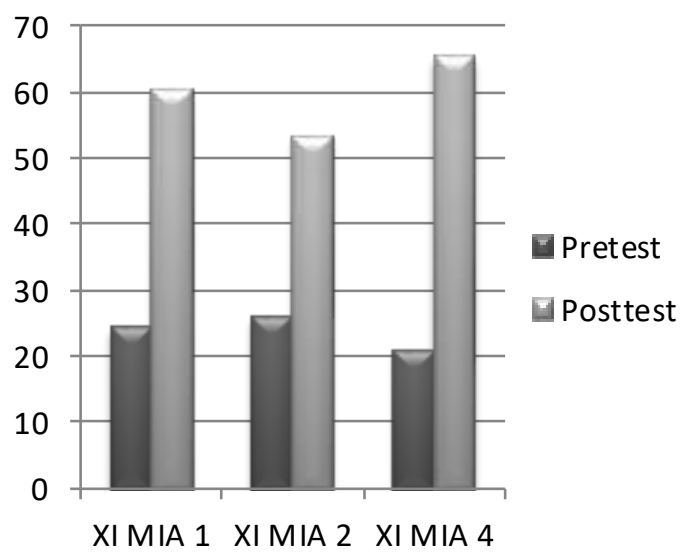

Gambar 2. Perbandingan kemampuan berpikir kritis saat Pretest dan Posttest

Uji prasyarat penelitian ini berkaitan dengan uji normalitas dan uji homogenitas. Uji normalitas dan homogenitas dilakukan pada hasil pretest dan posttest. Hasil uji homogenitas pretest adalah data termasuk dalam kategori homogen dengan taraf signifikansi 5\%, maka diperoleh nilai $\mathrm{F}_{\text {hitung }}$ lebih kecil dibandingkan dengan $F_{t a b e l}$, sedangkan untuk data posttest diperoleh nilai Fhitung sebesar 1,37. Nilai ini masih lebih kecil dibandingkan dengan nilai $F_{t a b e l}$ yang bernilai 2,21. Berdasarkan hasil ini dapat disimpulkan data kemampuan berpikir kritis peserta didik untuk pretest dan posttest termasuk dalam kategori homogen. Uji normalitas dilakukan untuk mengtahui data yang digunakan terdistribusi normal atau tidak. Uji normalitas merupakan syarat yang harus terpenuhi sebelum melakukan uji hipotesis. Berdasarkan hasil uji normalitas kemampuan berpikir kritis pada ketiga kelas eksperimen, diperoleh nilai $\chi^{2}$ hitung lebih kecil dibandingkan $\chi^{2}$ tabel untuk pretest dan posttest. Rata-rata nilai $\chi^{2}$ hitung kurang dari 12,59, sehingga dapat disimpulkan bahwa data terdistribusi secara normal.

Uji Hipotesis pada penelitian ini menggunakan Paired Sample $t$ test yang diolah dengan bantuan IBM SPSS 23. Uji Paired Sample $t$ test ini digunakan untuk mengetahui perbedaan nilai rata-rata sebelum perlakuan dan sesudah diberikan perlakuan pendekatan konflik kognitif. Hipotesis statistiknya yaitu $\mathrm{H}_{0}$ : Tidak terdapat perbedaan skor pretest dan posttest kemampuan berpikir kritis setelah penerapan pembelajaran dengan pendekatan konflik kognitif, sedangkan $\mathrm{H}_{\mathrm{a}}$ : Rata-rata skor posttest lebih besar dibandingkan dengan skor pretest kemampuan berpikir kritis setelah penerapan pembelajaran dengan pendekatan konflik kognitif. Kriteria pengambilan keputusan pada uji $\mathrm{t}$ berpasangan atau paired sample t test yaitu: jika nilai sig. (2-tailed) lebih kecil daripada 0,05 , maka $\mathrm{H}_{\mathrm{a}}$ diterima dan $\mathrm{H}_{0}$ ditolak.

Hasil uji hipotesis dengan bantuan IBM SPSS 23 diperoleh nilai signifikansi pada tiap kelas eksperimen lebih kecil dari $0,05 \%$, sehingga diperoleh kesimpulan bahwa rata-rata skor posttest lebih besar dibandingkan dengan skor pretest. Fakta ini menunjukkan bahwa penerapan pendekatan konflik kognitif berpengaruh positif terhadap kemampuan berpikir kritis. Hasil ini juga diperkuat dengan hasil penelitian sebelumnya mengenai pendekatan konflik kognitif. Setyowati et al. (2011) menyatakan 
bahwa konflik kognitif dalam pembelajaran fisika pada materi tekanan mampu menumbuhkan kemampuan berpikir kritis, penguasaan konsep dan hasil belajar kognitif peserta didik. Hasil tersebut memperkuat hasil penelitian ini, yaitu adanya pengaruh pendekatan konflik kognitif dalam meningkatkan kemampuan berpikir kritis peserta didik. Pendekatan konflik kognitif dapat dijadikan alternatif dalam pembelajaran, karena mampu meningkatkan kemampuan berpikir kritis. Peserta didik yang menyadari ketidakcocokan antara konsep ilmiah dengan konsep awalnya akan berupaya menyelesaikan masalah tersebut, sehingga meningkatkan kemampuan berpikirnya. Makhrus et al. (2014), pendekatan konflik kognitif akan menghubungkan peserta didik dalam pembelajaran aktif. Tantangan yang diberikan akan disajikan pada permulaan pembelajaran yaitu dengan meminta peserta didik untuk membuat sebuah penalaran atas prediksi dan estimasi untuk menjelaskan strategi yang akan digunakan dalam menyelesaikan permasalahan serta mereka akan akan diminta untuk mendukung pandangan mereka ke dalam sebuah pernyataan tertulis, gambar, atau model fisika.

\section{PENUTUP}

Berdasarkan hasil dan pembahasan yang telah dipaparkan dapat disimpulkan bahwa: 1) Tingkat kemampuan berpikir kritis peserta didik termasuk kategori tinggi saat proses pembelajaran dengan pendekatan konflik kognitif pada materi gelombang mekanik; 2) Pendekatan konflik kognitif berpengaruh positif terhadap kemampuan berpikir kritis pada materi gelombang mekanik peserta didik MAN 2 Mataram tahun Pelajaran 2017/2018. Pengaruh yang dimaksud adalah adanya peningkatan kemampuan berpikir kritis peserta didik pada ketiga kelas eksperimen, sehingga rata- rata skor posttest kemampuan berpikir kritis lebih besar dibandingkan dengan rata-rata skor pretest.

\section{REFERENSI}

Arend, B. 2009. Encouraging critical thinking in online threaded discussions. Journal of Educators Online, 6(1), 1-23.

Ennis, R.H. 1996. Critical Thinking. USA: Prentice-Hall, Inc.

Gunawan, Harjono, A., \& Sutrio. 2015. Multimedia Interaktif Dalam Pembelajaran Konsep Listrik Bagi Guru. Jurnal Pendidikan Fisika dan Teknologi, 1(1), 9-14.

Lee, G., Kwon, J., Park, S. S., Kim, J. W., Kwon, H. G., dan Park, H. K. 2003. Development of an instrument for measuring cognitive conflict in secondary level science classes. Journal of research in science teaching, 40(6), 585-603.

Makhrus, M \& Hadiprayitno, G. 2012. Penerapan Perangkat Pembelajaran Fisika Berorientasi Pembelajaran IPA Terpadu Tipe Connected. Jurnal Pendidikan dan Pembelajaran 19(2), 237-242.

Makhrus, M., Nur M., \& Widodo, W. 2014. Model Perubahan Konseptual dengan Pendekatan Konflik Kognitif. Jurnal PIJAR MIPA, 9(1), 20-25.

Muthmainnah, Rokhmat, J., dan Ardhuha, J. 2017. Pengaruh Penerapan Pembelajaran Fisika berbasis Eksperimen Virtual terhadap Motivasi dan Hasil Belajar Fisika Siswa Kelas $\mathrm{X}$ MAN 2 Mataram Tahun Ajaran 2014/2015. Jurnal Pendidikan Fisika dan Teknologi 3(1), 40-47.

Sagala, S. 2009. Konsep dan Makna Pembelajaran untuk Membantu Memecahkan Problematika Belajar dan Mengajar. Bandung: Alfabeta.

Schunk, D.H. 2012. Learning Theories An Educational Perspective. Yogyakarta: Pustaka Pelajar. 
Setyowati, A., Subali, B., \& Mosik. 2011. Implementasi pendekatan konflik kognitif dalam pembelajaran fisika untuk menumbuhkan kemampuan berpikir kritis siswa SMP kelas VIII. Jurnal Pendidikan Fisika Indonesia, 7(2), 89-96.

Treagust, D. F. 2013. An Intervention Study Using Cognitive Conflict to Foster Conceptual Change. Journal Science and Mathematic 36(1), 44-64.

Tuqalby, R., Sutrio, \& Gunawan. 2017. Pengaruh Strategi Konflik Kognitif terhadap Penguasaan Konsep pada Materi Fluida Siswa SMAN 3 Mataram tahun ajaran 2016/2017. Jurnal Pendidikan Fisika dan Teknologi, 3(1), 8-13.

Wiradana, I. W. G. (2012). Pengaruh Strategi Konflik Kognitif dan Berpikir Kritis Terhadap Prestasi Belajar IPA Kelas VII SMP Negeri 1 Nusa Penida. Jurnal Pendidikan IPA, 2(2), 1-19. 